\title{
HUBUNGAN DERAJAT NEUROPATI DENGAN KESEIMBANGAN FUNGSIONAL PADA PASIEN NEUROPATI DIABETIK
}

\section{Ria Desnita ${ }^{1}$}

\section{STIKes Mercubaktijaya Padang ${ }^{1}$}

Kutipan: Desnita, Ria. (2017). Hubungan Derajat Neuropati Dengan Keseimbangan Fungsional Pada Pasien Neuropati Diabetik. Jurnal Keperawatan Muhammadiyah, 2 (2)

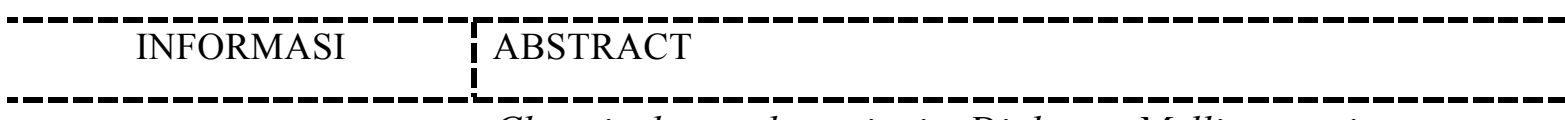

Chronic hyperglycemia in Diabetes Mellitus patients causes

\section{Korespondensi}

ria.desnita18@gmail.com complications of diabetic neuropathy. Impaired of balance in Diabetes Mellitus patients is associated with neuropathy complications that cause ischemia and alteration of function the nerves that regulate the balance. The study aimed to determine the correlation between level of neuropathy with functional balance in diabetic neuropathy patients. This study design was analytic cross sectional, recruited 132 diabetic neuropathy patients. Statistical analysis used Chi Square. This research was conducted in Poliklinik Penyakit Dalam RSUP DR. M. Djamil Padang. The results showed a significant correlation between level of neuropathy and functional balance in diabetic neuropathy patients ( $p=0.001 ; a=0.05)$. This

Keywords: diabetic neuropathy, level of neuropathy, functional balance study suggests the nurse to perform early detection and prevention of the risk of falls in diabetic neuropathy patients related to level of neuropathy and functional balance. 


\begin{abstract}
ABSTRAK
Hiperglikemia kronis pada pasien Diabetes Melitus menyebabkan komplikasi berupa neuropati diabetik. Gangguan keseimbangan pada pasien Diabetes Melitus dikaitkan dengan komplikasi neuropati yang menyebabkan iskemia dan perubahan fungsi pada saraf yang mengatur keseimbangan. Penelitian ini bertujuan untuk mengetahui hubungan derajat neuropati dengan keseimbangan fungsional pada pasien neuropati diabetik. Desain penelitian ini adalah analitik cross sectional dengan jumlah sampel 132 pasien neuropati diabetik. Analisis data menggunakan Chi Square. Penelitian ini dilakukan di Poliklinik Penyakit Dalam RSUP Dr. M. Djamil Padang. Hasil penelitian menunjukkan adanya hubungan antara derajat neuropati dengan keseimbangan fungsional pada pasien neuropati diabetik $(p=0,001 ; \alpha=0,05)$. Penelitian ini merekomendasikan perawat untuk melakukan deteksi dini dan mencegah resiko jatuh pada pasien neuropati diabetik terkait keparahan derajat neuropati dan perubahan keseimbangan fungsional.
\end{abstract}

Kata kunci: neuropati diabetik, derajat neuropati, keseimbangan fungsional

\section{PENDAHULUAN}

Diabetes Melitus (DM) adalah gangguan metabolik kronis yang dikarakteristikkan dengan tingginya kadar glukosa darah atau hiperglikemia (Center for Disease Control and Prevention [CDC], 2014). DM terjadi akibat tubuh tidak dapat memproduksi insulin dalam jumlah yang cukup atau tidak mampu menggunakan insulin secara efektif (International Diabetes Federation [IDF], 2015). Ketidakcukupan produksi insulin atau ketidakefektifan penggunaan insulin dalam tubuh menimbulkan gangguan mekanisme glukosa yang dicirikan dengan hiperglikemia (CDC, 2014).

Angka kejadian DM mengalami peningkatan setiap tahum. Prevalensi angka kejadian DM di dunia berdasarkan data World Health Organization (WHO) tahun 2014 adalah 422 juta jiwa atau $8,5 \%$ dari total populasi penduduk dunia. Berdasarkan perkiraan dari International Diabetes Federation (IDF) 1 dari 11 orang di dunia akan menjadi penderita DM pada tahun 2040 (IDF, 2015).

Di Indonesia, jumlah penderita DM pada tahun 2015 mencapai 7\% dari total populasi penduduk Indonesia (WHO, 2016). Hasil Riset Kesehatan Dasar (Riskesdas) tahun 2013 juga menunjukkan peningkatan prevalensi DM di Sumatera Barat, dari 1,2\% di tahun 2007 menjadi 1,8\% di tahun 2013 (Kementrian Kesehatan RI, 2013). Sedangkan di Rumah Sakit Umum Pusat Dr. M. Djamil Padang sendiri yang merupakan salah satu rumah sakit rujukan provinsi di daerah Sumatera Barat juga menunjukkan tingginya prevalensi penyakit DM. Pada tahun 2014 angka jumlah pasien DM di RSUP Dr. M. Djamil Padang mencapai 619 pasien di ruang rawat inap dan 7432 pasien yang berobat ke Poliklinik (Pusat Data dan Rekam Medik RSUP. Dr. M. Djamil, 2015).

DM dapat menimbulkan berbagai komplikasi. Salah satu komplikasi dari DM adalah neuropati diabetik. Neuropati diabetik adalah kerusakan saraf yang dapat bersifat fokal atau difus terjadi akibat paparan dari hiperglikemia kronis (Kuate-Tegueu, 
Temfack, Ngankou, Doumbe, Djientcheu, \& Kengne, 2015). Hampir $50 \%$ pasien dengan DM mengalami komplikasi neuropati (Kuate-Tegueu et al., 2015). Prevalensi neuropati pada pasien DM diperkirakan sebesar 8\% pada pasien yang baru terdiagnosa DM dan lebih dari $50 \%$ pada pasien yang sudah lama terdiagnosa DM (Deli, Bosnyak, Pusch, Komoly, \& Feher, 2014).

Iskemia pada saraf dan proses perubahan fungsi saraf terkait dengan komplikasi neuropati diabetik juga menyebabkan iskemia dan perubahan fungsi saraf yang mengatur keseimbangan (Kaya, 2014). Proses keseimbangan yang diatur oleh kerja sama saraf sensorik, motorik, dan proses biomekanik mengalami perubahan akibat hiperglikemia kronis. Sistem sensorik yang terdiri dari sistem vestibuler, sistem proprioseptif dan sistem visual mengalami penurunan fungsi pada pasien DM (Kaya, 2014).

Kondisi neuropati pada pasien DM menjadi faktor penyebab resiko jatuh dan gangguan keseimbangan (Singleton \& Smith, 2012). Gangguan keseimbangan akan berakibat pada peningkatan resiko cedera, penurunan produktivitas pasien dan akhirnya menurunkan kualitas hidup pasien (Synder, 2009).

Perbedaan derajat neuropati pada pasien DM mempengaruhi perubahan fungsi pada sistem saraf yang mengatur keseimbangan sehingga juga akan mempengaruhi besarnya perubahan gangguan keseimbangan fungsional pada pasien DM.

\section{METODE}

Penelitian ini menggunakan desain penelitian cross sectional dengan jumlah sampel 132 pasien neuropati diabetik yang berobat jalan di Poliklinik Penyakit Dalam RSUP Dr. M. Djamil Padang pada Bulan Mei 2016. Teknik pengambilan sampel yang digunakan adalah non probability sampling dengan consecutive sampling.

Kriteria inklusi dalam penelitian ini adalah pasien bersedia menjadi responden penelitian, pasien DM dengan skor hasil skrining menggunakan Michigan Neuropathy Screening Scale (MNSI) > 2, usia kurang dari 60 tahun. Sedangkan kriteria eksklusi dalam penelitian ini adalah pasien dengan edema pada kaki, memiliki skor 1 pada penilaian ulkus dengan MNSI, pasien dengan keluhan pusing dan riwayat vertigo, pasien dengan hipotensi ortostatik dan pasien dengan gangguan pendengaran.

Alat pengumpulan data yang digunakan dalam penelitian ini adalah format skrining neuropati dengan MNSI, format pengkajian karakteristik responden, dan instrumen Berg Balance Scale (BBS). Format skrining MNSI adalah format pemeriksaan fisik yang digunakan untuk mengidentifikasi calon responden penelitian dan menilai derajat neuropati. Nilai sensitivitas dari MNSI adalah $80 \%$ dan spesifisitas $100 \%$ (Zilliox et al., 2015).

Instrumen BBS digunakan untuk menilai keseimbangan fungsional. Nilai sensitivitas BBS adalah $55-82 \%$ dan nilai spesifisitas adalah $87 \quad-\quad 95 \%$ (Colon-Emeric, 2002).

Analisis data pada penelitian ini menggunakan Chi Square untuk melihat hubungan derajat neuropati dengan keseimbangan fungsional. Penelitian ini dilakukan setelah mendapat izin secara administratif. Penelitian ini juga dilakukan dengan menerapkan prinsip etika penelitian dan juga telah lolos kaji etik. 
HASIL

Karakteristik pasien neuropati diabetik yang menjadi responden penelitian berdasarkan usia didapatkan rerata usia responden adalah 51,95 tahun $(\mathrm{SD}=$ 5,96). Karakteristik responden berdasarkan lama menderita DM didapatkan rerata lama menderita DM adalah 9,11 tahun $(\mathrm{SD}=5,34)$. Data karakteristik responden pada penelitian ini terdapat pada tabel 1.1 berikut.

Tabel 1.1

Karakteristik Responden

Berdasarkan Usia dan Lama

Menderita DM di RSUP Dr. M.

Djamil Padang Tahun 2016 (n=132)

\begin{tabular}{lcrl}
\hline $\begin{array}{c}\text { Karakteristik } \\
\text { Responden }\end{array}$ & Mean \pm SD & $\begin{array}{l}\text { Min- } \\
\text { Maks }\end{array}$ \\
\hline Usia & 51,95 & \pm & $30-59$ \\
& 5,96 & & \\
\hline Lama DM & 9,11 & \pm & $2-32$ \\
& 5,34 & & \\
\hline
\end{tabular}

Hasil Penelitian juga menunjukkan distribusi dari karakteristik responden. Berdasarkan jenis kelamin didapatkan sebagian besar $(53,8 \%)$ responden berjenis kelamin perempuan. Dari hasil penelitian juga diketahui bahwa sebagian besar responden $(82,6 \%)$ dengan glukosa darah yang tidak terkontrol.

Berdasarkan derajat neuropati diketahui $47 \%$ responden dengan derajat neuropati ringan, $28,8 \%$ derajat neuropati berat dan $24,2 \%$ derajat neuropati sedang. Berdasarkan keseimbangan fungsional didapatkan sebagian besar responden $(59,1 \%)$ tidak terdapat gangguan keseimbangan fungsional. Distribusi karakteristik responden terdapat pada tabel 1.2 berikut.

Tabel 1.2

Distribusi Responden Berdasarkan Jenis Kelamin, Kontrol Gula Darah, Derajat Neuropati, dan Keseimbangan Fungsional di RSUP Dr. M. Djamil Padang Tahun $2016(n=132)$

\begin{tabular}{lcc}
\hline Karakteristik Responden & F & \% \\
\hline Jenis Kelamin & 61 & 46,2 \\
Laki-laki & 71 & 53,8 \\
$\quad$ Perempuan & 23 & \\
Kontrol Glukosa Darah & 109 & 17,4 \\
Terkontrol & & 82,6 \\
$\quad$ Tidak terkontrol & 62 & \\
Derajat Neuropati & 32 & 47,0 \\
Ringan & 38 & 24,2 \\
Sedang & & 28,8 \\
Berat & 54 & \\
Keseimbangan Fungsional & 78 & 40,9 \\
Ada gangguan & & 59,1 \\
Tidak ada gangguan &
\end{tabular}

Berdasarkan hasil analisis hubungan derajat neuropati dengan keseimbangan fungsional pada pasien neuropati diabetik menunjukkan bahwa terdapat hubungan antara derajat neuropati dengan keseimbangan fungsional $(\mathrm{p}=$ $0,001 ; a=0,05)$.

Hasil analisis sebanyak 9 orang responden $(14,5 \%)$ dengan derajat 
neuropati ringan mengalami gangguan keseimbangan fungsional, sedangkan responden dengan derajat neuropati sedang yang mengalami gangguan keseimbangan fungsional adalah sebanyak 16 orang $(50 \%)$ dan responden dengan derajat neuropati berat yang juga mengalami gangguan keseimbangan fungsional adalah sebanyak 29 orang $(76,3 \%)$.

Hasil analisis lebih lanjut berdasarkan nilai OR, dapat disimpulkan bahwa responden dengan derajat neuropati sedang beresiko 5,89 kali terjadinya gangguan keseimbangan fungsional dibandingkan responden dengan derajat neuropati ringan (CI 95\% OR=2,19; 15,84). Responden dengan derajat neuropati berat beresiko 18,98 kali terjadinya gangguan keseimbangan fungsional dibandingkan responden dengan derajat neuropati ringan (CI $95 \% \quad \mathrm{OR}=6,78 ;$ 53,09). Analisis hubungan bentuk kaki dengan keseimbangan fungsional terdapat pada tabel 1.3 berikut.

Tabel 1.3

Analisis Hubungan Derajat Neuropati dengan

Keseimbangan Fungsional Pada Pasien Neuropati Diabetik di RSUP Dr. M. Djamil Padang Bulan Mei 2016 (n=132)

\begin{tabular}{|c|c|c|c|c|c|c|c|c|}
\hline \multirow{3}{*}{$\begin{array}{l}\text { Derajat } \\
\text { Neuropati }\end{array}$} & \multicolumn{4}{|c|}{ Keseimbangan Fungsional } & & & \multirow{3}{*}{$\begin{array}{c}\text { OR } \\
(95 \% \mathrm{CI})\end{array}$} & \multirow{3}{*}{$\underset{\text { value }}{\mathrm{p}}$} \\
\hline & \multicolumn{2}{|c|}{$\begin{array}{l}\text { Tidak Ada } \\
\text { Gangguan }\end{array}$} & \multicolumn{2}{|c|}{$\begin{array}{c}\text { Ada } \\
\text { Gangguan }\end{array}$} & \multicolumn{2}{|c|}{ Total } & & \\
\hline & $\mathbf{n}$ & $\%$ & $\mathbf{n}$ & $\%$ & $\mathbf{N}$ & $\%$ & & \\
\hline Ringan & 53 & 85,5 & 9 & 14,5 & 62 & 100 & Pembanding & $0,001 *$ \\
\hline Sedang & 16 & 50,0 & 16 & 50,0 & 32 & 100 & $\begin{array}{c}5,89 \\
(2,19-15,84)\end{array}$ & $0,001^{*}$ \\
\hline Berat & 9 & 23,7 & 29 & 76,3 & 38 & 100 & $\begin{array}{c}18,98 \\
(6,78-53,09) \\
\end{array}$ & $0,001 *$ \\
\hline Total & 78 & 59,1 & 54 & 40,9 & 132 & 100 & & \\
\hline
\end{tabular}

*bermakna pada a: 5\%

\section{PEMBAHASAN}

Dari hasil penelitian didapatkan derajat neuropati paling banyak adalah neuropati derajat ringan yaitu sebesar $47 \%$. Sedangkan persentase neuropati derajat berat adalah $28,8 \%$ dan neuropati derajat sedang sebesar $24,2 \%$. Hasil penelitian ini berbeda dengan penelitian Agrawal et al. (2010) tentang diabetes, disfungsi vestibular dan jatuh pada 21.161 pasien DM. Penelitian Agrawal et al. (2010) mendapatkan persentase neuropati derajat ringan sebesar $74 \%$, derajat sedang $19 \%$ dan derajat berat $7,1 \%$.
Perbedaan prevalensi derajat neuropati yang ditemukan antara penelitian ini dan penelitian Agrawal et al. (2010) disebabkan karena perbedaan instrumen yang digunakan dalam penilaian neuropati. Pada penelitian Agrawal et al. (2010) penilaian neuropati hanya didasarkan pada pemeriksaan sensasi atau kebas, sedangkan pada penelitian ini penilaian neuropati didasarkan pada pemeriksaan fisik neuropati menurut MNSI.

Berdasarkan hasil penelitian juga didapatkan bahwa persentase gangguan keseimbangan fungsional lebih tinggi 
terjadi pada responden dengan derajat neuropati berat. Gangguan keseimbangan pada pasien DM dengan komplikasi neuropati menyebabkan terjadinya kerusakan saraf sensorik dan motorik yang mengatur keseimbangan tubuh (D'Silva et al., 2016).

Hasil penelitian Palma, Antigual, Martinez, Monrroy dan Gajardo (2012) tentang keseimbangan statis pada pasien DM tipe II dengan neuropati dan tanpa neuropati juga menunjukkan bahwa prevalensi gangguan keseimbangan statis lebih tinggi terjadi pada pasien DM dengan neuropati. Lebih lanjut dijelaskan bahwa neuropati berhubungan dengan gangguan keseimbangan statis pada pasien DM (Palma et al., 2012).

Proses neuropati pada pasien DM menyebabkan terjadinya disfungsi vestibular yang mengatur keseimbangan. Berdasarkan hasil penelitian Agrawal et al. (2010) juga menunjukkan bahwa prevalensi disfungsi vestibular lebih tinggi terjadi pada neuropati derajat berat yaitu sebesar 76\%. Hasil penelitian Fortaleza et al. (2012) tentang kontrol postural dan keseimbangan fungsional pada pasien neuropati diabetik juga menunjukkan bahwa semakin tinggi skor neuropati maka skor keseimbangan fungsional akan menurun.

Kondisi hiperglikemia kronik menyebabkan disfungsi vestibular dalam mempertahankan keseimbangan tubuh (D'Silva et al., 2016). Hiperglikemia menyebabkan glikosilasi dari mielin dan peningkatan AGEs, formasi ROS, aktivasi polyol dan protein kinase C. Proses ini menyebabkan digestif lisosom dalam jumlah besar pada saraf vestibulokoklearis, produksi berlebihan dari matrik ekstraseluler dan peningkatan droplet lipid dan lisosom pada jaringan penghubung utrikula dan sakula. Proses lebih lanjut akan menyebabkan gangguan difusi oksigen dan nutrisi, selubung mielin menipis dan penurunan diameter serabut akson. Akhir dari proses ini menyebabkan kerusakan fungsi pada vestibulokoklearis dan berujung dengan gangguan keseimbangan (D'Silva et al., 2016).

Neuropati menyebabkan kerusakan pada saraf sensorik dan motorik yang mengatur keseimbangan (Kaya, 2014). Hasil penelitian Palma et al. (2012) tentang keseimbangan statis pada pasien DM tipe II dengan neuropati dan tanpa neuropati menunjukkan bahwa prevalensi gangguan keseimbangan statis lebih tinggi terjadi pada pasien DM dengan neuropati. Lebih lanjut dijelaskan bahwa neuropati berhubungan dengan gangguan keseimbangan statis pada pasien DM (Palma et al., 2012). Proses keseimbangan tubuh diatur oleh kerja sama sistem saraf sensorik, motorik dan biomekanik. Pada neuropati sistem saraf sensorik yang terdiri dari sistem vestibular, sistem proprioseptif dan sistem visual mengalami penurunan fungsi. Penuruan fungsi dari sistem saraf ini akan menyebabkan penurunan kemampuan mengatur fungsi keseimbangan (Palma et al., 2012; Kaya, 2014).

Salah satu kerusakan saraf akibat neuropati yang paling berpengaruh terhadap fungsi keseimbangan adalah disfungsi vestibular dan disfungsi proprioseptif (Kaya, 2014; D'Silva et al., 2016). Disfungsi vestibular menyebabkan kerusakan pada fungsi vestibulokoklearis sehingga menyebabkan peningkatan resiko gangguan keseimbangan fungsional (D'Silva et al., 2016). 
Neuropati diabetik menyebabkan gangguan informasi somatosensori dan proprioseptif. Sistem somatosensori dan proprioseptif yang mengatur keseimbangan terdiri dari mekanoreseptor di otot, sendi dan kulit. Dengan adanya neuropati, terjadi penurunan sensitivitas kaki sehingga informasi mekanoreseptor dari telapak kaki menurun dan akhirnya mengakibatkan gangguan keseimbangan (Kaya, 2014).

\section{KESIMPULAN}

Hasil penelitian memberikan perspektif bahwa perbedaan derajat neuropati menyebabkan terjadinya perbedaan gangguan tingkat keseimbangan fungsional. Penilaian derajat neuropati dan gangguan keseimbangan dapat menjadi deteksi dini resiko jatuh dan cidera pada pasien neuropati diabetik. Jatuh atau cidera akan menyebabkan penurunan kemampuan dalam melakukan aktivitas, penurunan produktifitas dan akhirnya menurunkan kualitas hidup pasien.

\section{DAFTAR PUSTAKA}

Agrawal, Y., Carey, J. P., Santina, C. C. D., Schubert, M. C., \& Minor, L. B. (2010). Diabetes, vestibular dysfunction, and falls: Analyses from the national health and nutrition examination survey. Otology \& Neurology, 31, 14451450.

Center for Disease Control and Prevention. (2014). Diabetic report card. Retrieved from http:/www.cdc.gov/diabetes/pdfs/ library/diabetesreportcard2014.pd f

Colon-Emeric, C. S. (2002). Falls in older adults: Assessment and intervention in primary care.
Journal Hospital Physician, 30, 55-66.

Deli, G., Bosnyak, E., Pusch, G., Komoly, S., \& Feher, G. (2014). Diabetic neuropathies: Diagnosis and management. Neuroendocrinology, 98(4), 267280.

doi:http://dx.doi.org/10.1159/000 358728

D'Silva, L.,J., Lin, J., Staecker, H., Whitney, S. L., \& Kluding, P. M. (2016). Impact of diabetic complications on balance and falls: Contribution of the vestibular system. Physical Therapy, 96(3), 400-409. Retrieved from http://search.proquest.com/docvie $\mathrm{w} / 1772802056$ ? accountid $=17242$

Fortaleza, A. C. D. S., Chagas, E. F., Ferreira, D. M. A., Mantovani, A. M., Barela, J. A., Chagas, E. F. B., \& Fregonesi, C. E. P. T. (2013). Postural control and functional balance in individuals with diabetic peripheral neuropathy. Brazilian Journal of Kinanthropometry, 15(3), 305314.

International Diabetes Federation. (2015). IDF diabetes atlas 2015. Retrieved from http://www.diabetesatlas.org/reso urces/2015-atlas.html

Kaya, Defne. (2014). Proprioception: The forgotten sixth sense. USA: OMICS Groups eBooks.

Kementrian Kesehatan RI. (2013). Riset kesehatan dasar. Jakarta: Balitbang Kemenkes RI.

Kuate-Tegueu, C., Temfack, E., Ngankou, S., Doumbe, J., Djientcheu, V. P., \& Kengne, A. 
P. (2015). Prevalence and determinants of diabetic polyneuropathy in a sub-Saharan African referral hospital. Journal of the Neurological Sciences, 355, 108-112.

http://doi.org/10.1016/j.jns.2015.0 5.035

Palma, F. H., Antigual, D. U., Martinez, S. F., Monrroy, M. A., \& Gajardo, R. E. (2012). Static balance in patients presenting diabetes mellitus type 2 with and without diabetic polyneuropathy. Arq Bras Endocrinology Metabolism 57(9), 722-726.

Pusat Data dan Rekam Medik RSUP. Dr. M. Djamil. (2015). Data kunjungan pasien diabetes melitus. Padang: RSUP. Dr. M. Djamil.

Singleton, J. R., \& Smith, A. G. (2012). Diabetic neuropathy. Continuum (Minneapolis, Minn.), 18(1), 6084.

Synder, R. J., Cardinal, M., Dauphinee, D. M., \& Stavosky, J. (2010). A post-hoc analysis of reduction in diabetic foot ulcer size at 4 weeks as a predictor of healing by 12 weeks. Ostomy Wound Management, 56(3), 44-50.

World Health Organization. (2016). Global report on Diabetes. Retrieved from http://www.who.int/diabetes/glob al-report/en/

Zilliox, L. A., Ruby, S. K., Singh, S., Zhan, M., \& Russell, J. W. (2015).

Clinical neuropathy scales in neuropathy associated with impaired glucose tolerance. Journal of Diabetes and its Complications, 29(3), 372-377. doi:http://dx.doi.org/10.1016/j.jdiacomp .2015.01.011. 
Jurnal Keperawatan Muhammadiyah 2(2) 2017 
Jurnal Keperawatan Muhammadiyah 2(2) 2017 